\title{
Indigenous Peoples in UN REDD+ Negotiations: "Importing Power" and Lobbying for Rights through Discursive Interplay Management
}

\author{
Linda Wallbott ${ }^{1}$
}

\begin{abstract}
In this article I analyze the strategies of indigenous peoples as norm entrepreneurs in UN climate negotiations. I set out a conceptual linkage between the emerging literature on institutional interaction and social constructivist agency. It is shown, against the background of a descriptive account of the development of REDD+ negotiations within the UNFCCC, that indigenous peoples have been able to influence the agenda by crafting their immaterial power resources through the transfer of knowledge resources and normative instances from distinct institutions. This strategy of "importing power" to the target institution, the UNFCCC, was accompanied by support of key individuals and favorable national governments. Furthermore, indigenous peoples' demand to have their rights considered in the REDD+ agreement resonated with more established frames of global environmental politics that focus on synergies, cost-effectiveness, and management approaches. However, further research is required to figure out argumentative dynamics within the indigenous community itself and to identify the conditions that determined the level of success of their advocacy strategies.
\end{abstract}

Key Words: indigenous peoples; institutional interaction; institutional linkage; international negotiations; norm entrepreneurs; REDD+; UNDRIP

\section{INTRODUCTION}

"No rights, no REDD!" This was the catchy slogan that indigenous peoples' (IPs) representatives and their supporters chorused inside the venue of the 14th Conference of the Parties (COP) to the United Nations Framework Convention in Climate Change (UNFCCC) in 2008 in Poznan. They had taken the stage to demonstrate against the deletion of a reference in relation to indigenous peoples' rights (IPR) in negotiations on UNFCCC's prospective mitigation instrument 'Reducing Emissions from Deforestation and Forest Degradation including the conservation, sustainable management or forests and enhancement of forest carbon stocks' (REDD+). REDD+ aims at compensating developing countries financially for the costs incurred in preventing deforestation. Thus, by building on the payment for ecosystem services-model, it reiterates the dominant focus of liberal environmentalism that favors market-based approaches to environmental governance (Bernstein 2002). A plurality of institutional spaces under the UNFCCC and outside it has taken up the issue, and IPs, for their part, have pointed out widely that the rights of indigenous and forest peoples would be "directly affected by REDD measures" (Accra Caucus et al. 2008:1). In this paper I will analyze the ways in which IPs have operated as norm entrepreneurs in this institutional complex by connecting the argumentative reservoirs of distinct institutional spaces. Thus, by crafting argumentative and normative linkages across different institutional settings of their own peer group and in relation with government representatives, IPs have exerted strategic 'interplay management' and have strengthened and refined their initial arguments in UNFCCC negotiations. In this, they did not abate their lobbying activities toward a rights-based approach to REDD+ including an emphasis on the UN Declaration on the Rights of Indigenous Peoples (UNDRIP), which recognizes IPs' inherent substantive rights, including the right to selfdetermination, collective rights to lands, territories and resources, and cultural rights, but also their procedural rights and the provision of Free, Prior, and Informed Consent (FPIC). Importantly, the plural of the term "peoples" denotes IPs' collective rights and their status beyond aggregated indigenous individuals or communities (UNGA 2007). Through the import of argumentative resources into the UNFCCC context, IPs have stretched the limits of their "indirect agency," a term coined by Schroeder (2010) with view to IPs' exclusion from formal voting in international climate negotiations.

Hence, I set out an analytical framework that perceives argumentative linkages between distinct institutions as cornerstones of a discursive field, what $\mathrm{I}$ refer to as 'interinstitutional space.' Concurrently, constructing such linkages might further enhance the agency capacities and leverage the speaker position of norm promoting actors and the weight of their arguments within their target institution. This is a new approach to positioning actors and norm dynamics into the analysis of institutional interplay (cf. Selin and VanDeever 2003, Oberthür and Gehring 2011, Zelli et al. 2012) by relating it with International Relations' constructivist research on norm change and norm entrepreneurs. However, the research presented in this article hopefully presents a twofold complement as, to date, much important work on the role of IPs and local communities has focused on their contribution to the stewardship of ecosystems and ecosystem services and the implementation of conservation and environmental management in geographical territories (cf. Laird 1986, Terborgh 2000, Raymond et al. 2009). Correspondingly, the diversity of actors in the forestry sector has been dealt with in analyses of market driven governance, certification schemes, and private rule-making (cf. Cashore 2002, Bernstein and Cashore 2004, Gulbrandsen 2004, Pattberg 2005, Cashore et al. 2007). Also, a broad literature deals with nonstate actors in global environmental negotiations (cf. Falkner 2003, Humphreys 2004, Betsill and Corell 2008, Bernauer and Betzold 2012, Burgiel and Wood 2012, Bäckstrand 2006). However, so far, a detailed analysis of IPs' strategies toward international negotiations has been neglected.

Turning to empirics, a description of the development of REDD+ in the UNFCCC from 2005-2010 will be followed by a review of 
the increasing consideration of IPR in the negotiation texts. After some fierce debate on the issue, the Cancun Agreements of COP-16 in 2010 acknowledged IPs and local communities and their rights as part of the social safeguards to REDD+ and took note of UNDRIP. This marked a substantial redefinition of rights and responsibilities and an extension of recognized actors under the Convention. On this basis I will analyze how IPs have created and utilized institutional linkages and interinstitutional discursive spaces to build and to support their arguments in relation to REDD+. The article is based on my own qualitative research, i.e., participatory observation and more than 30 semistructured expert interviews with party delegates, IPs, and other civil society representatives at UNFCCC Conference of the Parties and intersessional meetings between 2010-2012; and the review and coding of primary and secondary documents. It concludes by sketching another factor that supported IPs' efforts in the negotiations: the dynamic meaning of the IPR-norm and the resulting adaptability of IPs' demand to dominant framings of sustainable development and forestry politics.

\section{LINKING THEORETICAL APPROACHES ON NORM ENTREPRENEURS AND NORM CHANGE WITH INTERPLAY MANAGEMENT}

\section{Norm entrepreneurs and norm change}

Any politics are shaped by institutions that are, at the most general level, clusters of rights, rules, and decision-making procedures that give rise to social practices, assign roles to participants in these practices, and govern interactions among occupants of these roles (Schroeder 2008:51). Hence, the design of institutions including sector-specific regimes like the UNFCCC concerns the shape of their normative foundation, with norms being defined as "collectively held or 'intersubjective' ideas and understandings on social life" (Finnemore and Sikkink 2001:392) or "collective expectations about proper behavior for a given identity," (Katzenstein 1996:5). Norms of justice and equity relate to the distribution of rights and responsibilities, of substantive rights like the right to culture or water and procedural rights like the right to participate in decision-making processes. These issues are at stake also in the debate on IPs' rights in international (climate) politics. However, norms always obtain a "dual quality" by giving structure and being socially constructed through interactive and (re)interpretative processes at the same time (Wiener 2007:49). At the same time, normative claims that might trigger norm change must be put forward and be responded to, they must be accepted or rejected. In other words: norm change is bound to agency.

'Agency,' in turn, refers to the power/ability of actors to display "conduct that possessed subjective meaning" (Campbell 2009:410). This understanding emphasizes motivation, intention, and goal-orientation but also "a strong strategic selfconsciousness" (McAdam et al. 1996:16) on the part of actors, just as with the perceived capacity to initiate and sustain corresponding action. In this sense, the agentic properties of socalled norm entrepreneurs show in the initiation and promotion of new norms or the attempt to strengthen the validity of a norm. Norm entrepreneurs are oftentimes equipped with strong credibility, attributed moral superiority, and expertise as knowledge brokers, and require an organizational platform from which to lobby for their endeavor (Finnemore and Sikkink 1998). Through this concept, nonstate actors like NGOs, international organizations, and epistemic communities (Haas 1992, Finnemore and Sikkink 1998, Risse et al. 1999), and also IPs enter the picture of international politics as engineers of change. Even though they are usually excluded from state-led, formal decisionmaking procedures, and disfavored with regard to the distribution of material resources in interaction frameworks of international negotiations ("indirect agency"; Schroeder 2010), they are able to develop alternative capabilities to exert immaterial power resources that give rise to "effective social and linguistic practices" (Holzscheiter 2005:726). In this vein, nonstate actors do not only network with each other; they also conduct what Betsill and Corell (2008) have referred to as "NGO diplomacy" by directly engaging with governments, including as observers in international negotiations. In this regard, nonstate actors represent the interests of their respective constituencies, which are oftentimes not territorially defined, engage in the exchange of information, and provide policy advice (cf. Betsill and Corell 2008). Herein, their capital resides in the discourses they represent and their abilities to promote these discourses within state-centred and state-created frameworks for communicative interaction (Holzscheiter 2005). Across levels, they pursue different kinds of soft power leadershipstrategies.

First, by resorting to strategic framing (Finnemore and Sikkink 1998, Payne 2001) norm entrepreneurs create an interpretative framework, in which certain aspects of an issue are presented as problematic and illegitimate. Thus, discursive strategies like dispersing information, (re)framing issues, and shaming and blaming positions them to exert ideational leadership, also called directional or intellectual leadership, by shaping the perspectives of participants in institutional bargaining as to what might be desirable and feasible. They identify particular causes of the problem, point out who is in charge to act, and propose morally adequate solutions, a standard "against which others will be judged" (Gupta and Ringius 2001:282). Thereby norm entrepreneurs create social pressure, establishing "the boundaries within which states must formulate their responses" (Betsill and Corell 2008:33). In such framing processes agents can be expected the create linkages between their new claims and already established ideas (Klotz 1995). Second, entrepreneurial/ instrumental leadership (Gupta and Ringius 2001) makes use of diplomatic and political skills like issue-linkage, integrative structuration, bridge-building, and mobilizing networks and coalitions of allies (Young 1991, Underdal 1994, Andresen and Agrawala 2002).

However, it is neither assumed that the participation of nongovernmental norm entrepreneurs automatically translates into influence nor that a particular form of state action would follow from it. It has been shown that the influence of norm entrepreneurs in negotiations is biggest when state actors require their knowledge resources about policy options and consequences in situations that are characterized by situation-specific insecurities (Brühl2003). Correspondingly, a norm entrepreneur's "rhetoric of change" (Gamson and Mayer 1996) develops assertiveness especially in such instances when the suggested framing is related and resonates with an existing normative framework. Subsequently, others might adjust their behavior by persuasion or as strategic adaptation (Checkel 2001) on the basis of altered cost/benefit calculations. 


\section{Norm entrepreneurs as interplay managers}

I assume that actors can add to their capital/power resources as norm entrepreneurs and advocates of norm change via the intentional and goal-oriented formation of discursive spaces across institutions. This perspective adds a new dimension to the research program on the management of institutional interaction or 'interplay management' (Oberthür and Stokke 2011a) in face of structural regime complexity (Raustiala and Victor 2004, Alter and Meunier 2009, Orsini 2013 with a similar argument from a social network analysis perspective). The management concept implies that actors are able to deal with institutional interaction, a situation in which "one institution affects the development or performance of another institution" (Stokke and Oberthür 2011:4), in an anticipating, reflective, intentional, goal-oriented, and coordinated way at various political levels. Three analytical considerations apply.

First, to date, the capacity of actors to shape regime complexity, the plurality of institutions that relate to the same subject, has been attributed above all to powerful states. These are considered to prevent norm emergence and the proliferation of unwanted norms by effectively employing cross-institutional "forumshopping" strategies that favor their interests best (Krasner 1983:16, Braithwaite and Drahos 2000, Jupille and Snidal 2005, Benvenisti and Downs 2007, Drezner 2009). On the other hand, especially developing countries and nonstate actors are often not able to send delegations with comparable material force and manpower to international negotiations. Particularly in face of parallel deliberations on similar policy issues in different institutions, as well as their restricted capacity to issue sidepayments or package-deals and state-based decision-making, they are often only attributed some constrained agency in international politics. However, such perspectives limit their attention to agency in the sense of agents' "ability to prescribe behavior" (Schroeder 2010:320). By focusing on the agentic reservoirs of powerful states in dictating the rules and result of the game by effectively employing cross-institutional strategies, such perspectives risk losing sight of the ways in which also nonhegemonic norm entrepreneurs might deal with the institutional fragmentation of the global political order, and how this impacts on the quality of their participation as well as on interactive processes in global governance. In this sense, formalistic and functionalist approaches to the study of institutional interaction risk sidelining broader approaches to the concept of agency that conceive of it as the "ability to initiate and maintain a program of action" (Campbell 2009:407), thereby also neglecting those norm entrepreneurial activities that deliberately construct interinstitutional discursive spaces to foster their interests.

Second, to capture such activities we can draw on studies that have already considered the framing of knowledge reservoirs in the context of "cognitive interaction" and of "normative interaction"/“interaction through commitment." The latter describes processes in which the obligatory character of another institution's policy instrument is reiterated, and in which the substantive or operational norms of one institution come to be seen as contradicting or validating those of another institution (Oberthür and Gehring 2011:36; see also Oberthür and Stokke $2011 b: 321)$. The former describes a mechanism in which one institution's knowledge and information is distributed, thereby modifying the order of preferences of actors relevant to the target institution (Oberthür and Gehring 2011:37). However, these studies have so far not conceived of these mechanisms as being at the strategic disposal of actors to leverage their agency position and to import power into negotiations within their target institution. Thus, in addition, I suggest the further disaggregation of the causal mechanism of cognitive interaction into two submechanisms, namely "knowledge brokering" and "capacity building" (terms also employed by Biermann and Siebenhüner 2009). In this paper, knowledge brokering relates to the gathering, synthesizing, processing, and disseminating of issue-specific information, across different institutions. Capacity building implies assisting other representatives in preparations for negotiations, between different formal and/or informal institutional arenas. Both submechanisms seem to be at the core of norm entrepreneurial soft power strategies, and might take place horizontally, i.e., within one peer group or within one group that has the same formal standing, or vertically, i.e., between different political levels or between actors that differ with regard to their formal standing. Third, the understanding of interplay management that is applied in this paper goes beyond an assessment of the causal mechanisms through which power resources might be transferred from one institution to another. Rather, the interinstitutional spaces that develop from those activities are explicitly regarded as overlapping argumentative spaces or fields of contestation, a notion that opens up the possibility to capture processes of (re)interpretation of norms. For changes in the meaning of norms might come along with their invocation through norm entrepreneurs, and in particular with their import into new contexts in the course of discursive interplay management.

In sum, the analytical approach introduced in this paper links the research program on norm entrepreneurs with the emerging literature on institutional interaction and interplay management. It is geared to considering normative dynamics and political transnationalization beyond a purely functionalist focus on the implications of overlapping regimes for policy effectiveness on the ground. Before I demonstrate the applicability of this perspective on norm entrepreneurs as agents of interplay management by depicting the strategies of IPs in UN REDD+ negotiations, I describe the negotiation history of REDD+ and the development of formal references to IPR. Their main elements imply the right to self-determination and land (tenure), as well as the right to participate in decision-making processes (see also Campese et al. 2009).

\section{THE DEVELOPMENT OF REDD+ AND IPR UNDER THE UNFCCC}

\section{A RED(D+) agenda}

The item on reducing emissions from deforestation (RED) in developing countries was formally introduced into UNFCCC negotiations at COP-11 in 2005 by a submission of Papua New Guinea and Costa Rica. The submission framed deforestation as a technical issue of land-use change emissions. A process for further consideration started at the 24th session of the Subsidiary Body for Scientific and Technological Advice (SBSTA) in 2006. After parties and accredited observers had submitted their views, SBSTA deepened the technocratic approach to the issue, considering relevant scientific, technical, and methodological 
issues, and providing proposals on policy approaches and positive incentives for related mitigation. In Bali 2007, on the basis of 21 received submissions that contained the views of 68 Parties, 4 submissions by intergovernmental organizations, and 13 submissions by NGOs (Sanz 2007), SBSTA reported back to COP-13. This conference, with document 2/CP.13, adopted a decision on "Reducing emissions from deforestation in developing countries: approaches to stimulate action" (UNFCCC 2007a), broadening the scope of action to reduce emissions from forest degradation (REDD). Following this decisive progress, which was "backed by much greater political will and larger sums of money" (Burgiel and Wood 2012:142) than previous forest processes under the UN, two parallel working tracks have been concerned with the issue: SBSTA initiated a program of work on methodological issues, and the Ad Hoc Working Group on Longterm Cooperative Action (AWG-LCA) initiated a consideration of policy approaches and positive incentives relating to REDD. Also, the Bali outcome (1/CP.13, 1(b)(iii) UNFCCC 2007a) had already included the ' + ' measures, i.e., conservation, the sustainable management of forests, and enhancement of forest carbon stocks, but these would only gain equal recognition as the components of deforestation and forest degradation at COP-14 in Poznan. There, however, no official decisions were taken on the mechanism. One year later, the only formal decision of COP-15 in 2009 was SBSTA's draft decision 4/CP.15 on "Methodological guidance for activities relating to reducing emissions from deforestation and forest degradation and the role of conservation, sustainable management of forests and enhancement of forest carbon stocks in developing countries" (UNFCCC 2010a). Also, parties started to consider a decision draft text, which covered the scope of activities, guiding principles and safeguards, approaches and means of implementation, and the question of measurement, reporting, and verification of actions. In the end, on the basis of an extended mandate, AWG-LCA continued negotiations and adopted a REDD+ decision as the main substantial outcome of the COP-16 negotiations in 2010 (UNFCCC 2010b).

Along with the UNFCCC negotiations, since 2008 a broader institutional complex on REDD+ has evolved. Next to the Convention process, the issue is dealt with in voluntary venues (see also Corbera and Schroeder 2011, Reinecke et al. 2014), namely the government-based interim REDD+ Partnership, which was set up in 2010 "to scale up actions and finance" for REDD+ initiatives (REDD+ Partnership, http://reddpluspartnership. org/en/), as well as in two multilateral and multistakeholder platforms established in 2008 that are concerned with developing countries' readiness to prepare for and to implement REDD+, the World Bank's Forest Carbon Partnership Facility (FCPF) and UN-REDD. Whereas IPs lobbied across those different venues, given UNFCCC's most encompassing set-up in terms of party membership and scope of policies, IPs can be considered to have had a special interest in having their rights acknowledged under the Convention.

\section{Evolvement of the debate on IPR in $\operatorname{RED}(\mathrm{D}+)$ negotiations}

A review of documents and party submissions to SBSTA and AWG-LCA meetings from 2005-2010 reveals that IPR, later coined as part of the social safeguards to REDD+, have travelled from the margins to the center of negotiations, partly in conjunction with references to local communities. In the original proposal of 2005 there was no mention of IPs or IPR. A general assumption noted that "in the absence of revenue streams from standing forests, communities and governments in many developing countries have little incentive to prevent deforestation" (Governments of Papua New Guinea and Costa Rica 2005:4). A main SBSTA-document from this time, a background paper to a RED-Workshop in 2006, included general concerns of a few environmental NGOs and some quantitative references from Bolivia on the expansion of indigenous territories (UNFCCC 2006a). Also in the submissions to SBSTA-24 in Bonn in 2006, parties overall did not employ an explicit rights language (UNFCCC 2006b,c). Only Bolivia, in its individual statement as well as in a joint statement with Costa Rica, Nicaragua, and Papua New Guinea, presented some remarks on the linkage between land tenure and community property rights. Possible cobenefits were not highlighted, but Central American countries clarified that "the burden of reducing or avoiding deforestation falls on stakeholders such as peasants, indigenous peoples, small farmers and ranchers" (UNFCCC 2006 $b: 105$ )

This first phase started to wane at SBSTA-26 in 2007, when Tuvalu became the first party to deploy stronger language in a submission that contained the country's views on issues relating to reducing emissions from deforestation, and in which it proposed an alternative Forest Retention Incentive Scheme (UNFCCC 2007b; see also section on IPs' engagement with governments). One of its benefits would be that "it is less likely to infringe on the rights of indigenous and local communities because the communities would be directly involved in the management of the activity" (UNFCCC 2007b:17). Also, Tuvalu reflected on the possibility of integrating the principles of the UN Draft Declaration on the Rights of Indigenous Peoples in programs on forestry, land use, and economic development. Later in 2007, during SBSTA-27, Tuvalu called for the prevention of perverse consequences of reducing emissions from deforestation, including "avoiding consequences that may infringe the rights of indigenous peoples and local communities" (UNFCCC 2007c:3). Falling behind this suggestion, the outcome of COP-13 only "[recognizes] also that the needs of local and indigenous communities should be addressed when action is taken to reduce emissions from deforestation and forest degradation in developing countries" (UNFCCC 2007a:8). Whereas submissions to the first AWGLCA sessions did not elaborate extensively on indigenous people (s), at AWG-LCA-2 parties had been invited to submit to the secretariat ideas and proposals on paragraph 1 of the Bali Action Plan.

Together with following submissions to AWG-LCA-5/6 (2009) these clearly set out parties' positions on IPR, bringing forward various framings and justifications of the issue, including the relevance of IPs' participation for the effectiveness of conservation and policy implementation, the necessity of respect for their property rights, dignity and culture. The revised negotiating text of AWG-LCA-6 (UNFCCC 2009a) contained for the first time some explicit, albeit still bracketed and related to national circumstances, rights-based language, as well as a reference to UNDRIP including FPIC. Only a few months earlier, SBSTA-29 at COP-14 in 2008, Poznan, had still omitted the plural of the term "peoples," and had thereby failed to comply with UNDRIP. Instead, it recognized the need to promote "the full and effective participation of indigenous people and local communities, taking into account national circumstances and 
noting relevant international agreements" (UNFCCC 2008:4) and invited Parties and accredited observers to submit "their views on issues relating to indigenous people and local communities for the development and application of methodologies" (UNFCCC 2008:2). In particular, Canada, the U.S., Australia, and New Zealand rejected the inclusion of any rights-language related to the standing of IPs. At COP-15 at the end of 2009 parties could still not agree on such wording in the Copenhagen Accord. Specifically, a reference to UNDRIP was sidelined again; yet, the adopted draft decision of SBSTA (there was no decision in the AWG-LCA) considered "the need for full and effective engagement of indigenous peoples and local communities in, and the potential contribution of their knowledge to, monitoring and reporting of activities relating to decision 1/CP.13, paragraph 1(b)(iii)" (UNFCCC 2009b:1, emphasis added). Furthermore, parties encouraged "as appropriate, the development of guidance for effective engagement of indigenous peoples and local communities in monitoring and reporting" (UNFCCC 2009b:2).

All in all, in this second phase between 2008 and 2009, the discourse on IPR intensified and became more differentiated. Also, progress was neither linear nor simultaneous in the two negotiation bodies, and the AWG-LCA seemed basically to be more open to acknowledge the political issue of rights-based language. Regarding submissions dealing with IPs' issues, parties kept quiet after Copenhagen, with the exception of Tuvalu, Bolivia, and the ALBA group, which at that time included Bolivia, Cuba, Ecuador, Nicaragua, and Venezuela.

In the facilitating texts of AWG-LCA-10/11 (2010) the rightsbased language including the reference to UNDRIP was preserved, yet only in relation to national circumstances. However, at AWG-LCA-12 in Tianjin in October 2010 conflict on IPR, driven by Bolivia and Saudi Arabia, broke up again. Reportedly, however, Saudi Arabia's move to bracket the section on safeguards, of which IPR are part, was a strategic manoeuvre, turning the matter into a bargaining chip to promote carbon dioxide capture and storage (CCS) in geological formations, for which Saudi Arabia and Qatar had been major sponsors in the negotiations. When it became clear that in the Cancun Agreements CCS would be eligible for carbon credits under Kyoto's Clean Development Mechanism, there was no further need to hold IPR hostage. Furthermore, after the failure of the Copenhagen negotiations, the Mexican host government of COP-16, managed to get the negotiations back on track throughout 2010. At the end of this phase of reconsolidation in 2010, AWG-LCA-13 ended with the adoption of the Cancun Agreements. The general spirit of the Agreements, as reflected in the Preamble, considers IPs by:

Noting resolution 10/4 of the United Nations Human Rights Council on human rights and climate change, which recognizes that the adverse effects of climate change have a range of direct and indirect implications for the effective enjoyment of human rights and that the effects of climate change will be felt most acutely by those segments of the population that are already vulnerable owing to geography, gender, age, indigenous or minority status and disability. (UNFCCC 2010b)
More specifically, the social safeguards for REDD, spelled out in the second paragraph to the Appendix of the decision, require among others the:

(c) Respect for the knowledge and rights of indigenous peoples and members of local communities, by taking into account relevant international obligations, national circumstances and laws, and noting that the United Nations General Assembly has adopted the United Nations Declaration on the Rights of Indigenous Peoples;

(d) The full and effective participation of relevant stakeholders, in particular, indigenous peoples and local communities [...].

Furthermore, safeguard (e) includes the footnote:

Taking into account the need for sustainable livelihoods of indigenous peoples and local communities and their interdependence on forests in most countries, reflected in the United Nations Declaration on the Rights of Indigenous Peoples, as well as the International Mother Earth Day (UNFCCC 2010b).

However, various caveats apply: First, the safeguards are not part of the operational text of the Cancun Agreements but are relegated to the Annex. Second, UNDRIP is merely noted, which is rather weak language in international law, and is qualified with reference to its conditionality upon national circumstances and laws. At this point, they were neither legally binding for parties (Werksman 2010) nor operational, but parties are instead requested to promote and to support the safeguards and to develop an information system to track their implementation. For that matter, institutional questions regarding the monitoring, reporting, and verification (MRV) of information have dominated the negotiations since 2010. However, despite these constraints, IPs deemed the Cancun decision a big success (Interview with national delegate, non-Annex I-party/IPs representative, May 2012, Bonn, personal communication).

\section{INDIGENOUS PEOPLES AS NORM ENTREPRENEURS AND INTERPLAY MANAGERS}

In fleshing out the main lines of development of the formal REDD+-IPR-nexus in the UNFCCC negotiations, it turns out that indigenous rights took hold particularly during 2008/2009. As I will demonstrate, at that time IPs commenced considerable activism in constructing interinstitutional spaces relating to their own constituency, and in lobbying efforts toward state addressees, thereby putting more weight behind their claim to incorporate IPR in REDD+. Notably, I will neither work out the details of different coalitions within the IPs community itself, which take different positions for example on the issue of finance, or the desirability of REDD+ as such. Nor will I engage with a debate on indigeneity or on the impact of self-identification as the main mechanism through which one person is to be counted as member of this group (UNPFII 2006, Canessa 2007). For the general argument on indigenous norm entrepreneurs as agents of interplay management, these considerations can be left aside. At this point, it is sufficient to state that IPs from different backgrounds have shared concerns for recognition of their rights in the UNFCCC process in general and with a view to the REDD+ 
outcome in particular, even on the basis of distinguishing themselves from local communities (Interview with national delegate, non-Annex I-party/IPs representative, May 2012, Bonn, personal communication). Because REDD+ would be implemented in forest-rich developing countries that have very often shared not only a colonial past but also national exclusion of IPs from political processes, these experiences considerably shaped their perception of the issue's historicity (Interview with national delegate, non-Annex I-party/IPs representative, May 2012, Bonn, personal communication). IPs were aware that the future implementation of REDD+ policies would impact heavily on their livelihood conditions, which is why their rights would have to be guaranteed in negotiations outcomes, policy formulation, and implementation.

\section{Interinstitutional knowledge brokering and capacity building among indigenous peoples}

Inside the UNFCCC, the International Indigenous Peoples Forum on Climate Change (IIPFCC) assembles representatives from Africa, Asia, and Latin America, and serves as the official indigenous caucus to the Convention to which IPs became an acknowledged constituency in 2001. From this organizational platform a main part of indigenous advocacy work that targets specifically at the negotiations is coordinated and prepared (Interview with national delegate, non-Annex I-party/IPs representative, May 2012, Bonn, personal communication). Also, IPs have regularly submitted observer statements to both negotiation tracks of REDD+ (see http://unfccc.int/ parties observers/ngo/submissions/items/3689.php). In this context, inter-institutional dynamics have helped to build procedural and substantial capabilities and soft power resources within the IPs community. These would support their substantial participation in the REDD+ negotiations, as the following examples indicate.

To start, several IPs representatives from different regions pointed out in interviews in December 2011 and May 2012 that the UN Permanent Forum on Indigenous Issues (UNPFII) served as an important arena for discussion and learning processes. Here IPs representatives would draw on examples from processes under other international bodies to strengthen their arguments in UN REDD+ negotiations, for example by inviting the inspection panel of the World Bank to the Permanent Forum to learn more about relevant policy mechanisms (Interview with national delegate, non-Annex I-party/IPs representative, May 2012, Bonn, personal communication). The fact that, in the end, the report of UNPFII's 2008 session on climate change mitigation measures (Tauli-Corpuz and Lynge 2008) included critical views on carbon trading and the REDD+ mechanism, can be regarded as one example of increasing self-assurance of IPs' position as norm promoting actors in the policy discourse. Also, the UNPFII recommended that the UNFCCC and relevant parties should develop mechanisms for IPs' participation, including the establishment of a working group on local adaptation measures and traditional knowledge. Notably, the concluding session in May 2008 was chaired by Vicky Tauli-Corpuz, the reputable founder of the indigenous organization TEBTEBBA who would later become cochair of UNFCCC's SBSTA and who had been involved in the climate negotiations as party delegate before. Without exception, interviews declared her experience and presence in a prominent position of the UNFCCC process (also in terms of IPs' engagement with negotiators and governments) a crucial factor for the continuous promotion of IPR and the supportive structuration of the negotiations in terms of ideational and entrepreneurial leadership.

Furthermore, IPs have collaborated outside the UN process, held workshops, and produced a range of policy documents, which would then feed into the statements of IPs representatives in the international negotiations (exemplarily Tebtebba 2008-2009). Relevant declarations include the Declaration on Climate Change and Indigenous Peoples of El Salvador (CCNIS 2009), the Anchorage Declaration (IPGSCC 2009), and the Mandaluyong Declaration of the Global Conference on Indigenous Women, Climate Change and REDD+ (Tebtebba 2010). Especially in comparison with earlier declarations (all the following documents are available from http://www.indigenousclimate.org) like the Albuquerque Declaration (1998), the Lyon Declaration of the First International Forum of Indigenous Peoples and Local Communities on Climate Change (2000), the Hague Declaration of the Second International Forum of Indigenous Peoples and Local Communities on Climate Change (2000), and the Quito Declaration on Climate Change Negotiations (2000), it shows that IPs have increasingly been able to display their pragmatic policy-specific abilities (Interview with African IPs representative, May 2012, Bonn, personal communication). Thus, the content of the declarations and statements increasingly included specific numbers, scientific argumentation, and policy proposals. In turn, this could have served to increase IPs' credibility as a respectable authority and as knowledge brokers inside international climate politics, which are heavily based on the technology-driven standardization of information. After all, by pointing out the "scientifically proven role of forests in reducing greenhouse gas emissions" (Interview with national delegate, non-Annex I-party/ IPs representative, May 2012, Bonn, personal communication), IPs framed their interest not as a particularist undertaking but as a matter of universal concern, which supposedly lowers the threshold for its acceptance by others:

They [the governments] know that how forests have been
managed is bad.... What will you do if the people decide
that they don't like it [the issue lobbied for]?... You have
to show that it is in the interest of the bigger society to
respect these things and do the right things after having
done the wrong thing for so many years (Interview with
national delegate, non-Annex I-party/IPs representative,
May 2012, Bonn, personal communication).

The above examples of cognitive institutional interaction indicate the relevance of distribution of knowledge among IPs themselves to found the basis for their norm entrepreneurial activities in the climate diplomacy game at the international level. As such, it would allow them to exert leadership activities by drafting alternative language for negotiation texts (for example COICA 2009, FPP 2009, IAIP 2009, IIPFCC 2009). However, also in the course of more direct active engagement with governments and international negotiators, IPs readily spread their lobbying activities across different forums.

Interinstitutional engagement with negotiators and governments In engaging with party negotiators and governments, IPs have been able to exhibit and increase their agentic capacities across the different institutions that deal with REDD+, thereby creating an overlapping sphere of moral pressure and pragmatic reasoning 
to advocate for norm change in the UNFCCC itself. Whereas the REDD+ Partnership, FCPF, and UN-REDD differ with regard to their set-up and composition of actors, IPs together with supportive governments and key individuals were able to initiate awareness-raising processes, pushing for additional interaction through commitment. They have been included in preparatory FCPF processes since 2008 and are members of its technical advisory panels (Bosquet 2012). Also, from 2009 onward the Policy Board of UN-REDD has included IPs representatives. Exemplarily, one interviewee reflected on the disseminating effect of those multiforum activities: "It is their [UN-REDD's] responsibility to inform the countries that receive UN-REDD money, to understand what this means. Sure we have informed and pushed them: you are a UN body, that there is a declaration you need to follow, a UN declaration and it is your obligation to implement it" (Interview with national delegate, non-Annex Iparty/IPs representative, May 2012, Bonn, personal communication).

Regarding the Partnership, IPs organizations and civil society groups had from its inception criticized the lack of inclusivity and disregarding of indigenous concerns (FPP2010a). After "a heated campaign in Tianjin" stakeholders were granted status as selffunded observers in 2010 but IPs have continued to call for full partner status (Lehr 2013) and to target the platform on the basis of capacity-building within their own peer group. Exerting ideational and entrepreneurial leadership, they have pointed out the weaknesses of the Partnership's policies and proposed alternative, more appropriate language (FPP 2010b). Thus, despite the continuing limitations, the Partnership is perceived as a space for lobbying IPs' interests through supportive individuals and governments: By being detached from UNFCCC's formal negotiations but displaying partial overlap in individual membership with it at the same time it "[enhanced] human relationships - people more convenient with each other, more friendly and seeing each other more as human beings instead of diplomats etc. It makes a lot of difference if there are more spaces like that ... it is also a process of education" (Interview with national delegate, non-Annex I-party/IPs representative, May 2012, Bonn, personal communication).

Likewise, the relevance of the underlying mechanism of awareness raising and education was confirmed by a former national delegate, who had participated in different international environmental negotiations, with a view to the important issue of the plural in the term 'indigenous peoples':

\section{[T] hese issues are typical CBD things, you know. There they have been discussed extensively, and here you are talking with climate change negotiators ... that was the first time they were talking about the role of indigenous people - indigenous peoples ... I think only during the negotiations they realized actually that there is some sensibilities behind that (Interview with former national delegate, Annex I-party, May 2012, Bonn, personal communication).}

Next to those dynamics in various institutional venues of the REDD+ complex, IPs' interplay management strategies also played out in direct interaction with national governments. Thus, already Tuvalu's early and door-opening support for IPR language in REDD+ negotiations can be traced back to the personal engagement of the country's former UN Ambassador with IPs during his term in office, and to the national significance of traditional practices (E-mail correspondence with national delegate, personal communication). Another important booster for IPs' visibility was Bolivia's indigenous president Evo Morales, who formally supported their claims in international processes through statements and appearances in meetings. In parallel to intense negotiations under the UNFCCC in April 2010, the World's Peoples Conference on Climate Change and the Rights of Mother Earth brought together more than 35,000 delegates from social movements and organizations from 140 countries (Government of Bolivia 2010) as well as various Latin American governments in Cochabamba, Bolivia. This event provided IPs, in particular from South America, and their supporters with more network structures and argumentative resources on procedural and substantive questions in the UN climate process, thereby indicating overlap with IPs' own knowledge brokering and capacity building. The claims that were incorporated in various output documents from this conference were far-reaching. The People's Agreement on Climate Change called upon the international community to respect the Rights of Mother Earth and to fully restore "violations to those rights" (Climate and Capitalism 2010:5). Also it "condemn[ed] market mechanisms" (Climate and Capitalism 2010:9) and was detailed on IPR beyond a mere reference to UNDRIP, including the demand "to give legal recognition to claims over territories, lands and natural resources ... full and effective implementation of the right to consultation, participation and prior, free and informed consent of indigenous peoples in all negotiation processes, and in the design and implementation of measures related to climate change" (Climate and Capitalism 2010:9). In the complementary Indigenous People's Declaration it was criticized "that international negotiation spaces have systematically excluded the participation of Indigenous Peoples. As a result, we as Indigenous Peoples are making ourselves visible in these spaces, because as Mother Earth has been hurt and plundered, with negative activities taking place on our lands, territories and natural resources, we have also been hurt" (Climate and Capitalism 2010:13-14).

On the one hand, according to a former EU delegate, the mandate that Bolivia as a UNFCCC party deducted from this conference, a rather radical normative framing complemented with a strong criticism of market-based finance schemes for REDD+ (Government of Bolivia 2010; see also Bäckstrand and Lövbrand 2006), was considered too rigid to be a useful token for international negotiations (Interview with former national delegate, Annex I-party, May 2012, Bonn, personal communication). Thus, Bolivia's actions in the multilateral setting were not considered as a suitable input and thoroughly consistent. However, on the other hand, as one interviewee explicitly acknowledged, "the topic [of indigenous rights] was more discussed because of them [Bolivia]" (Interview with national delegate, non-Annex I-party/IPs representative, May 2012, Bonn, personal communication). This was the case, for example, when the country together with some oil exporting parties entered into some hard-nosed bargaining on the issue of IPR vs. carbon dioxide capture and storage in October 2010 (Interviews with former national delegate, Annex I-party, and with national delegate, non-Annex I-party/IPs representative, May 2012, Bonn, personal communication).

Another country that had supported IPs' matters was Norway by engaging in capacity-building activities like workshops and seminars for IPs outside the UNFCCC process, and regular 
participation of government representatives in IPs' side events at the negotiations. According to one party delegate from Norway, this interaction across different institutional spaces has helped the official negotiators to learn from IPs' concerns so that, in the end, they could function as transmitters between the indigenous constituency and the multilateral setting (Telephone interview with national delegate, Annex I-party, June 2012, personal communication).

Finally, the transparent and inclusive style with which the Mexican host government conducted the preparatory process to COP-16, which would finally adopt the REDD+ safeguards, was valued tremendously (Interview with South-American IPs representative, December 2010, Cancun, personal communication). Indeed, in 2010 the Mexican government organized special consultations in the form of a technical workshop on UNFCCC negotiations in general and building blocks (including REDD+) in particular between party delegates from Norway, Denmark, Peru, Bolivia, Maldives, Tuvalu, and Panama, and IPs. The recurring meetings backed the supportive governments to assume the role of multiplicators within the international negotiations. Notably, Mexico's Special Representative on Climate Change was favorably inclined to the issue having previously served as the first president of the UN Human Rights Council, guiding the negotiations on UNDRIP. The Declaration itself, adopted in 2007 by the General Assembly (UNGA 2007), can be regarded as a manifestation of the recognition of IPs'. It strengthened IPs' position as speakers and agents in global politics. Whereas IPs themselves had proclaimed to be an entitled constituency prior to this event, the Declaration meets with their moral demands for respect and inclusion, and formalized the procedural right to FPIC as well as the substantive rights to self-determination (Art. 3), to maintain their ethnic identities and cultural values (Art.8), and calls upon states to prevent "[a]ny action which has the aim or effect of dispossessing them of their lands, territories or resources," (Art.8.2b). This engagement of the international community, which expanded through the reversed positions of the Declaration's former opponents Canada, USA, Australia, and New Zealand, has been called upon by IPs during their partylobbying activities in the UNFCCC context, thereby evoking normative interaction through commitment. The emerging discursive interinstitutional space in turn increased the pressure for governments to comply with the norm and to acknowledge IPR also under the UNFCCC (Interview 2011b). Still, the Declaration is a non-binding text and notable differences continue to exist in comparison with states' subject position in international law like the ability to ratify international agreements. Nevertheless, next to the ILO Convention 169 it served as a focal point around which the 'loose ends' of IPs' claims could coalesce, also in the negotiations on REDD+: "[T]he fact that we won the declaration is already a big thing, it shortcuts so many processes, we don't have to come and spell out everything, it is there already" (Interview with national delegate, non-Annex I-party/IPs representative, May 2012, Bonn, personal communication).

All in all, the persistent norm promoting activities of IPs were shaped considerably by the deliberate construction of discursive interinstitutional spaces for contestation, in their own constituency as well as in interaction with state addressees and supporters of their lobbying activities. In the course of discursive interplay management IPs placed their arguments at the intersection of various international institutions. Hence, government representatives have been confronted with IPs' REDD+ concerns in different set-ups and atmospheres, the dynamics of which fed back into UNFCCC negotiations (Interview with national delegate, non-Annex I-party/IPs representative, May 2012, Bonn, personal communication). Also, the support of transmitter- or multiplicator-actors in UNFCCC bodies and at the interface of formal negotiations and related discussions was fundamental in influencing the REDD+ agenda and in building the enabling environment in which the idea of IPR could mature. Thus, as a constituency, IPs, alongside their visible individual members, have exerted discursive agency and ideational leadership. As interviewees have pointed out, IPs representatives were increasingly recognized as valuable learning partners for national delegates. By using those interinstitutional strategies, IPs managed to stay vocal and to keep their interests on the agenda, thereby further substantiating their indirect agency capacities.

\section{Connectivity with dominant framings}

However, examining the framing of IPR in more detail (the following analysis is based on the UNFCCC documents included in the literature cited), it becomes apparent that IPs' initial narrative would gain momentum within the multilateral climate community when, in 2008/2009, a diversification of framings took place. At that time, IPs' concerns turned out to be adaptable to more consolidated discourses of global environmental governance and forestry politics. This supported the resonance of their norm promoting activities within the party community and the institutional logic of the UNFCCC. Still in 2006, Bäckstrand and Lövbrand placed debates on indigenous people in a "critical discourse" on forest plantation projects in the climate regime. They convincingly differentiated between a "radical resistance" and a more "reform-oriented" approach in this stream and contrasted it with a discourse of ecological modernization and green governmentality. However, negotiations have progressed considerably since their analysis, and the debate on IPR can no longer be exclusively subsumed under the heading of critical discourse. Instead, in the course of negotiating REDD+, IPR have been tagged with at least three frames: a normative, a synergistic, and a technocractic-administrative framing. The following sketch depicts this diversity.

First, in a normative framing the inherent rights of IPs and local communities are promoted because of their intrinsic value and even their relationship with Mother Earth. It is emphasized that they need to be protected not only from the negative impacts of climate change but also from adverse consequences of adaptation and mitigation activities. Proponents of this framing also highlight the intrinsic relation between local communities/IPs and natural forests, the value of IPs' culture and their own representative institutions and organizations, and the need to include these groups in negotiations. Accordingly, IPs supportive of this frame refer to themselves as rights-holders, not as stakeholders or constituency groups (Jintiach 2011; Interview with African IPs representative, December 2011, Durban, personal communication).

This framing is generally combined with a legalistic notion that calls upon respect for UNDRIP and FPIC, consequently acknowledging the subject position of IPs, on this basis also 
honouring the plural of the term peoples, and absorbing IPs' land tenure rights. It also accompanies references to other international agreements like the Ramsar Convention, and the ILO Convention 169 as relevant sources for policy formulation and implementation under the UNFCCC. Strong middle powers that support this normative framing emphasize furthermore the necessity to include IPs in the course of policy implementation to ensure sustainable practices on the ground. This discursive bridge-building has facilitated the resonance of IPs' demand for recognition with alternative framings of international forest governance, which other actors promote more comprehensively.

One such alternative framing rests with the tradition of a synergistic win-win narrative, which resembles the "ecological modernization" narrative of Bäckstrand and Lövbrand (2006). Here, the recognition of IPR is above all justified instrumentally on the basis of their relevance for the success and sustainability of implementing REDD+. In this framing, which somewhat resembles a New Public Management Discourse, participation is suggested as a necessary means to increase the acceptability of the mechanism and to maximize the potential of REDD+ because of the overlap and functional interplay of IPs' livelihoods and the space of policy implementation. This frame simultaneously contains references to cost-effectiveness, shared benefits, the relevance of REDD+ for the realization of broader social, economic, and environmental objectives, as well as for guaranteed livelihoods and the fulfilment of IPs' needs. As such, it resembles the broader normative context of "liberal environmentalism" (Bernstein 2002, see also Zelli et al. 2012).

Finally, in accordance with an operational discourse and the technocratic-administrative notion of green governmentality, IPs' participation is promoted on the basis of their ability to participate in the reporting of MRV, turning them into something like the managers of REDD+. This framing, however, has a somewhat subordinate standing and appears as an accompanying feature of the more dominant emphasis on effectiveness and efficiency, but it often serves as a measure to equip the normative discourse with some pragmatism as well. One important element is the emphasis on the value of indigenous and traditional knowledge, which should not only be respected but also disseminated widely to achieve the pragmatic ends of adaptation and mitigation.

In a longitudinal perspective the diversification of frames arose in the period between the end of 2008 (with COP-14 in Poznan) and AWG-LCA-6 in June 2009 when REDD+ negotiations intensified. It can be deduced that the debate gained momentum when it became clear that REDD+ negotiations were actually about material, geographical spaces on the ground, and that IPs' concerns were not only related to indigenous history but also adhered to climate-related functionality, which could be translated into standardized technocratic language:

They [national governments] also recognized that the topics they are talking about are really territories of indigenous peoples, and that is a fact and that is proven. They know very well the situation related to the forests in their countries, they know that indigenous peoples have customary claims to these territories ... It [the collaboration of indigenous peoples $]$ is also one thing to ensure that it [REDD+] succeeds (Interview with national delegate, non-Annex I-party/IPs representative, May 2012, Bonn, personal communication).

Such character of the synergistic and the technocraticadministrative framings also confirm findings from previous analysis on nonstate actors in global environmental politics (Brühl 2003); these tend to become recognized especially under those conditions in which their policy expertise and knowledge are required above average. In sum, even though the initial normative momentum lost some drive in the course of negotiations, it provided for a valuable entry point for IPs' claims. In later negotiations the text and talk resonated increasingly "with the discursive nerves of state actors" (Holzscheiter 2005:734). At that time, the issue of IPR had become a focal point in the REDD+ negotiations that could no longer be ignored if states wanted to make the prospective agreement acceptable for their home audience (Interview with national delegate, non-Annex Iparty, December 2011, Durban, personal communication).

\section{CONCLUSIONS}

In this article I presented a new analytical perspective on nonstate actors as managers of institutional interplay under conditions of structural regime complexity. It started from the observation that IPs in international climate negotiations have lobbied heavily to have their rights (IPR) formally respected in what came to be adopted as the Cancun Agreements of UN climate talks in 2010. To account for this development, IPs were depicted as norm entrepreneurs who leveraged their argumentative capital as agents of interplay management. They widely and vocally argued against (negotiations on) a forest-based mitigation mechanism that disregarded IPR, and presented a morally adequate solution to this perceived deficit, namely the inclusion of rights-language in the REDD+ agreement. In this lobbying process, indigenous actors intentionally mobilized, built bridges, and crafted their organizational and ideational power resources within their own peer group as well as in exchange with governments. This leads to the more general conclusion that the construction of discursive interinstitutional spaces, drawing on linkages of cognitive interaction and interaction by commitment, allows norm entrepreneurs to increase the impact of their demands for norm change. Strategic interplay management in the face of institutional complexity can thus be regarded as one element of nonstate actors' diplomacy and as a way of importing power. As one interviewee who participated in international negotiations both as an IPs representative and national delegate concluded in an interview (May 2012, Bonn, personal communication):

$[W]$ e bring our indigenous partners in these international negotiations and these people are the ones who know the issue as they live in these communities. By bringing them here we enhance their capacities to understand the issue and process and train them and meet national level officials.... And then we engage with other UN agencies as well as with the World Bank and make our partners participate in those meetings. We do as well the research and we teach our communities how to do the research. By doing all these things, they acquire more knowledge on the traditional systems ... we have a sizable core of people that are able to influence the process. Also 
at the local level, we train the communities. So all of these kinds of elements have to be brought into the whole strategy and this is how we succeeded.

Thus, IPs substantiated their entrepreneurial and ideational leadership and (indirect) agency-capacities in international REDD+ negotiations by generating discursive power and capabilities through the consolidation and transfer of knowledge, the creation of expertise, and connective framing in nonUNFCCC arenas, thereby reframing $\operatorname{RED}(\mathrm{D}+)$ from a technocratic to a normative issue (cf. Humphreys 2008). However, this framing of the imported IPR-norm was not conclusive because the issue came to be attributed with different meanings that could again be related to the initial, more techno-economic paradigm of forest policies. Thus, in the end, the inclusion of IPR language was also facilitated by making it resonate with other goals and dominant framings of global climate politics. Furthermore, a seemingly nonparticularistic nature of IPs' interests was discursively constructed by referring to the general value of forest conservation and sustainable forest management. Finally, the inclusion of the specific IPR language into the final agreement can be read as an adjustment of decision makers', that is, states', behavior according to IPs' claims. In other words, indigenous participation in the process yielded some influence.

However, further research is required to elaborate more on the beneficial circumstances that supported the effectiveness of IPs' norm promoting activities, including conditions of the constituency's recognition, and on the type and level of their influence. Also, this will require drawing a more differentiated picture of indigenous voices inside and outside the formal negotiation process because they have been presented as rather unanimous in this paper. As such, a detailed discourse analysis of institutional and normative dynamics would be able to take into account IPs' standing in relation to other actors but also patterns of conflict, domination, and representation within the IPs community itself. It is plausible that also within this grouping especially those actors with comparably strong organization skills are able to deal with the fragmented setting of global governance.

In the end, with a view to the quality of norm development in the UNFCCC at least two interpretations seem feasible. On the one hand, the recognition of IPR and UNDRIP has led to an expansion/diversification of UNFCCC's normative foundation through the additional accommodation of new norms of justice that serve as a new point of justification for future political action. The range of recognized actors has widened, and the "institutional morality" (Hardin 1998) of the UNFCCC has thickened. From this perspective, it would seem appropriate to declare the change of a regime (Krasner 1983), change of a paradigm (Hall 1993) or change of UNFCCC's meta-governance structure (Kooiman 2003). On the other hand though, another reading of the story would suggest that giving some space to IPs' demands through the formal inclusion of their rights in the respective documents was merely a means to (re)stabilize the faltering climate regime, securing the dominance of market-based solutions and liberal environmentalism. In such a reading, IPs' entrance into a new institutional space can also be regarded as an instrumental strategy by governments to ensure governmentality and control over vast areas of indigenous territories on the ground, possibly in an attempt to delegitimize internal political struggles. Hence, from an analytical perspective the formal acknowledgement of IPR should be regarded as one first step of a political process, not as its end. Accordingly, further research on effectiveness and legitimacy of REDD+ should pay attention to the questions whether the gains in mention of IPR are paralleled by supportive national action or if they rather commensurate with potential losses (cf. Baez 2011, VisserenHamakers et al. 2012, Forsyth and Sikor 2013, on the politics of operationalizing REDD+ activities see also McDermott et al. 2012), and how the REDD+ complex beyond the UNFCCC will develop on the matter. Finally, research that follows upon the meaning of IPR could align with literature on local processes of norm translation and norm reinterpretation as well as the influence of local knowledge systems on stewardship of ecosystems and ecosystem services (cf. Folke 2004, Toledo et al. 2003).

Responses to this article can be read online at: http://www.ecologyandsociety.org/issues/responses. $\mathrm{php} / 6111$

\section{Acknowledgments:}

I am grateful to Kristin Rosendal, Steinar Andresen, Olav Schram Stokke, Jørgen Wettestad, Ben Kamis, Ulrike Höppner, the coeditors of this volume, and the anonymous reviewers for their comments on earlier versions of this article.

\section{LITERATURE CITED}

Accra Caucus on Forests and Climate Change, Accion Ecologica, Friends of the Earth International, Indigenous Peoples' Forum on Climate Change, Rainforest Foundation Norway, Rainforest Foundation UK, and Tebtebba Foundation. 2008. Indigenous Peoples, local communities and NGOs outraged at the removal of rights from UNFCCC decision on REDD. Tebtebba, Baguio City, Philippines. [online] URL: http://www.tebtebba.org/index.php/ content/122-no-rights-no-redd

Alter, K. J., and S. Meunier. 2009. The politics of international regime complexity. Perspectives on Politics 7(1):13-24. http://dx. doi.org/10.1017/S1537592709090033

Andresen, S., and S. Agrawala. 2002. Leaders, pushers and laggards in the making of the climate regime. Global Environmental Change 12(1):41-51. http://dx.doi.org/10.1016/ S0959-3780(01)00023-1

Bäckstrand, K. 2006. Democratizing global environmental governance? Stakeholder democracy after the World Summit on Sustainable Development. European Journal of International Relations 12(4):467-498. http://dx.doi.org/10.1177/1354066106069321

Bäckstrand, K., and E. Lövbrand. 2006. Planting trees to mitigate climate change: contested discourses of ecological modernization, green governmentality and civic environmentalism. Global Environmental Politics 6(1):50-75.

Baez, S. 2011. The "right" REDD framework: national laws that best protect indigenous rights in a global REDD regime. Fordham Law Review 80:821-875. 
Benvenisti, E., and G. W. Downs. 2007. The empire's new clothes: political economy and the fragmentation of international law. Stanford Law Review 60(2):595-631.

Bernauer, T., and C. Betzold. 2012. Civil society in global environmental governance. Journal of Environment and Development 21(1):62-66. http://dx.doi.org/10.1177/1070496511435551

Bernstein, S. 2002. Liberal environmentalism and global environmental governance. Global Environmental Politics 2 (3):1-16. http://dx.doi.org/10.1162/152638002320310509

Bernstein, S., and B. Cashore. 2004. Non-state global governance: is forest certification a legitimate alternative to a global forest convention? Pages 33-63 in J. J. Kirton and M. J. Trebilcock, editors. Hard choices, soft law. Voluntary standards in global trade, environment and social governance. Ashgate, Aldershot, UK.

Betsill, M., and E. Corell, editors. 2008. NGO diplomacy: the influence of nongovernmental organizations in international environmental negotiations. MIT Press, Cambridge, Massachusetts, USA.

Biermann, F., and B. Siebenhüner. 2009. The role and relevance of international bureaucracies: setting the stage. Pages 1-14 in F. Biermann and B. Siebenhüner, editors. Managers of global change: the influence of international environmental bureaucracies. MIT Press, Cambridge, Massachusetts, USA. http://dx.doi.org/10.7551/ mitpress/9780262012744.003.0001

Bosquet, B. 2012. Overview of the FCPF and engagement with indigenous peoples. Presentation at the Asia Indigenous Peoples Dialogue, 24-28 September, Chaing Mai, Thailand. Forest Carbon Partnership Facility. [online] URL: http://www. forestcarbonpartnership.org/sites/fcp/files/Documents/tagged/FCPF $\%$ 200verview $\% 20$ EN.pdf

Braithwaite, J., and P. Drahos. 2000. Global business regulation. University Press, Cambridge, UK.

Brühl, T. 2003. Nichtregierungsorganisationen als Akteure internationaler Umweltverhandlungen. Campus Verlag, Frankfurt am Main, Germany.

Burgiel, S. W., and P. Wood. 2012. Witness, architect, detractor. The evolving role of NGOs in international environmental negotiations. Pages 127-148 in P. Chasek and L. M. Wagner, editors. The roads from Rio. Lessons learned from twenty years of multilateral environmental negotiations. Routledge, London, UK.

Campbell, C. 2009. Distinguishing the power of agency from agentic power: a note on Weber and the "black box" of personal agency. Sociological Theory 27(4):407-418. http://dx.doi. org/10.1111/j.1467-9558.2009.01355.x

Campese, J., T. Sunderland, T. Greiber, and G. Oviedo, editors. 2009. Rights-based approaches. Exploring issues and opportunities for conservation. CIFOR and IUCN, Bogor, Indonesia.

Canessa, A. 2007. Who is indigenous? Self-identification, indigeneity, and claims to justice in contemporary Bolivia. Urban Anthropology 36(3):195-237.

Cashore, B. 2002. Legitimacy and the privatization of environmental governance: how non-state market-driven governance systems gain rule-making authority. Governance 15 (4):503-529. http://dx.doi.org/10.1111/1468-0491.00199

Cashore, B., G. Auld, S. Bernstein, and C. McDermott. 2007. Can non-state governance 'ratchet up' global environmental standards? Lessons from the forest sector. Review of European, Comparative \& International Environmental Law 16(2):158-172. http://dx.doi.org/10.1111/j.1467-9388.2007.00560.x

Checkel, J. T. 2001. Why comply? Social learning and European identity change. International Organization 55(3):553-588. http:// dx.doi.org/10.1162/00208180152507551

Climate and Capitalism. 2010. Documents of the World People's Conference on Climate Change and the Rights of Mother Earth. South Branch Publications. [online] URL: http://readingfromtheleft. com/PDF/CochabambaDocuments.pdf

Consejo Coordinator Nacional Indígena Salvadreño (CCNIS). 2009. Declaration on Climate Change and Indigenous Peoples of El Salvador. [online] URL: http://www.tebtebba.org/index.php/ all- resources/category/84-redd-and-ad-and-indigenous-peoples

Coordinadore de las Organizaciones Indigenas de la Cuenca Amazonica (COICA). 2009. SBSTA Submission. COICA, Quito, Ecuador. [online] URL: http://unfccc.int/resource/docs/2009/ $\underline{\text { smsn/ngo/112.pdf }}$

Corbera, E., and H. Schroeder. 2011. Governing and implementing REDD+. Environmental Science \& Policy 14 (2):89-99. http://dx.doi.org/10.1016/j.envsci.2010.11.002

Drezner, D. W. 2009. The power and peril of international regime complexity. Perspectives on Politics 7(1):65-70. http://dx.doi. org/10.1017/S1537592709090100

Falkner, R. 2003. Private environmental governance and international relations: exploring the links. Global Environmental Politics 3(2):72-87. http://dx.doi.org/10.1162/152638003322068227

Finnemore, M., and K. Sikkink. 1998. International norm dynamics and political change. International Organization 52 (4):887-917. http://dx.doi.org/10.1162/002081898550789

Finnemore, M., and K. Sikkink. 2001. Taking stock: the constructivist research program in international relations and comparative politics. Annual Review of Political Science 4:391-416. http://dx.doi.org/10.1146/annurev.polisci.4.1.391

Folke, C. 2004. Traditional knowledge in social-ecological systems. Ecology and Society 9(3): 7. [online] URL: http://www. ecologyandsociety.org/vol9/iss3/art7/

Forest Peoples Programme (FPP). 2009. Views on issues relating to indigenous peoples and local communities for the development and application of methodologies. FPP, Moreton-in-Marsh, UK. [online] URL: http://unfccc.int/resource/docs/2009/smsn/ngo/104. pdf

Forest Peoples Programme (FPP). 2010b. FPP submission to Oslo Partnership Agreement (draft). FPP, Moreton-in-Marsh, UK. [online] URL: http://www.indigenousportal.com/Climate-Change/ FPP-submission-to-Oslo-Partnership-Agreement-draft.html

Forest Peoples Programme (FPP). 2010a. REDD+ partnership launched amid concerns over indigenous peoples' rights while UN 
negotiations resume. FPP, Moreton-in-Marsh, UK. [online] URL: http://www.forestpeoples.org/n1/node/1299

Forsyth, T., and T. Sikor. 2013. Forests, development and the globalisation of justice. Geographical Journal 179(2):114-121. http://dx.doi.org/10.1111/geoj.12006

Gamson, W., and D. Mayer. 1996. Framing political opportunity. Pages 275-290 in D. McAdam, J. D. McCarthy, and M. Zald, editors. Comparative perspectives on social movements. Political opportunities, mobilizing structures, and cultural framings. Cambridge University Press, New York New York, USA. http:// dx.doi.org/10.1017/CBO9780511803987.014

Government of Bolivia. 2010. Submission by the plurinational state of Bolivia to the ad-hoc working group on long-term cooperative action. Draft Negotiating Text. United Nations Framework Convention on Climate Change, Bonn, Germany. [online] URL: http://unfccc.int/files/meetings/ad_hoc_working_groups/ lca/application/pdf/bolivia awglca10.pdf

Governments of Papua New Guinea and Costa Rica. 2005. Reducing emissions from deforestation in developing countries: approaches to stimulate action. FCCC/CP/2005/MISC.1. United Nations Framework Convention on Climate Change, Montréal, Québec, Canada. [online] URL: http://unfccc.int/resource/ docs/2005/cop11/eng/misc01.pdf

Gulbrandsen, L. H. 2004. Overlapping public and private governance: can forest certification fill the gaps in the global forest regime? Global Environmental Politics 4(2):75-99. http://dx.doi. org/10.1162/152638004323074200

Gupta, J., and L. Ringius. 2001. The EU's climate leadership: reconciling ambition and reality. International Environmental Agreements: Politics, Law and Economics 1(2):281-299. http://dx. doi.org/10.1023/A:1010185407521

Haas, P. M. 1992. Introduction: epistemic communities and international coordination. International Organization 46 (1):1-35. http://dx.doi.org/10.1017/S0020818300001442

Hall, P. 1993. Policy paradigms, social learning, and the state: the case of economic policymaking in Britain. Comparative Politics 25(3):275-296. http://dx.doi.org/10.2307/422246

Hardin, R. 1998. Institutional morality. Pages 126-153 in R. E. Goodin, editor. The theory of institutional design. Cambridge University Press, Cambridge, UK. http://dx.doi.org/10.1017/ $\underline{\text { CBO9780511558320.006 }}$

Holzscheiter, A. 2005. Discourse as capability: non-state actors' capital in global governance. Millennium - Journal of International Studies 33:723-746. http://dx.doi.org/10.1177/03058298050330030301

Humphreys, D. 2004. Redefining the issues: NGO influence on international forest negotiations. Global Environmental Politics 4 (2):51-74. http://dx.doi.org/10.1162/152638004323074192

Humphreys, D. 2008. NGO influence on international policy on forest conservation and the trade in forest products. Pages 149-176 in $\mathrm{M}$. Betsill and E. Corell, editors. NGO diplomacy: the influence of nongovernmental organizations in international environmental negotiations. MIT Press, Cambridge, Massachusetts, USA.
Indigenous Peoples' Global Summit on Climate Change (IPGSCC). 2009. The Anchorage Declaration. United Nations Framework Convention on Climate Change, Bonn, Germany. [online] URL: http://unfccc.int/resource/docs/2009/smsn/ngo/168. pdf

International Alliance of Indigenous and Tribal Peoples of the Tropical Forests (IAIP). 2009. Submission to SBSTA, on behalf of International Indigenous Peoples' Forum on Climate Change. United Nations Framework Convention on Climate Change, Bonn, Germany. [online] URL: http://unfecc.int/resource/ docs/2009/smsn/ngo/108.pdf

International Indigenous Peoples' Forum on Climate Change (IIPFCC). 2009. Proposed language for negotiating text. United Nations Framework Convention on Climate Change, Bonn, Germany. [online] URL: http://unfccc.int/resource/docs/2009/ smsn/ngo/167.pdf

Jintiach, J. C. 2011. Indigenous peoples participation at UNFCCC. Presented at SBI In-session Workshop to further develop ways to enhance the participation of observer organizations. United Nations Framework Convention on Climate Change, Bonn, Germany. [online] URL: http://unfccc.int/files/

conference programme/application/pdf/110608 ipo_afternoon sbi insession wkshop.pdf

Jupille, J., and D. Snidal. 2005. The choice of international institutions: cooperation, alternatives and strategies. http://dx.doi. org/10.2139/ssrn.1008945

Katzenstein, P., editor. 1996. The culture of national security: norms and identity in world politics. Columbia University Press, New York, New York, USA.

Klotz, A. 1995. Norms in international relations. Cornell University Press, Ithaca, New York, USA.

Kooiman, J. 2003. Governing as governance. Sage, London, UK.

Krasner, S. 1983. International regimes. Cornell University Press, Ithaca, New York, USA.

Laird, S. A., editor. 1986. Biodiversity and traditional knowledge. Equitable Partnerships in Practice. Earthscan, London, UK.

Lehr, D. 2013. Indigenous peoples must be represented in REDD+ partnership. Indigenous Peoples' Climate Change Portal, Baguio City, Philippines. [online] URL: http://www.indigenousclimate. org/index.php?option $=$ com content $\&$ view $=$ article $\& i d=201 \%$

3Aindigenous-peoples-must-be-represented-in-reddpartnership\&catid=3\%3Anews\&lang=en

McAdam, D., J. D. McCarthy, and M. N. Zald. 1996. Opportunities, mobilizing structures, and framing processes toward a synthetic, comparative perspective on social movements. Pages 1-21 in D. McAdam, J. D. McCarthy, and M. N. Zald, editors. Comparative perspectives on social movements. Political opportunities, mobilizing structures, and cultural framings. Cambridge University Press, Cambridge, UK.

McDermott, C. L., L. Coad, A. Helfgott, and H. Schroeder. 2012. Operationalizing social safeguards in REDD+: actors, interests and ideas. Environmental Science and Policy 21:63-72. http://dx. doi.org/10.1016/i.envsci.2012.02.007 
Oberthür, S., and T. Gehring. 2011. Institutional interaction: ten years of scholarly development. Pages 25-58 in S. Oberthür, and O. S. Stokke, editors. Managing institutional complexity. Regime interplay and global environmental change. MIT Press, Cambridge, Massachusetts, USA. http://dx.doi.org/10.7551/mitpress/97802$\underline{62015912.003 .0002}$

Oberthür, S., and O. S. Stokke, editors. 2011a. Managing institutional complexity. Regime interplay and global environmental change. MIT Press, Cambridge, Massachusetts, USA. http://dx. doi.org/10.7551/mitpress/9780262015912.001.0001

Oberthür, S., and O. S. Stokke. 2011b. Conclusions: decentralized interplay management in an evolving interinstitutional order. Pages 313-341 in S. Oberthür, and O. S. Stokke, editors. Managing institutional complexity. Regime interplay and global environmental change. MIT Press, Cambridge, Massachusetts, USA. http://dx. doi.org/10.7551/mitpress/9780262015912.003.0012

Orsini, A. 2013. Multi-forum non-state actors: navigating the regime complexes for forestry and genetic resources. Global Environmental Politics 13(3):34-55. http://dx.doi.org/10.1162/ GLEP a 00182

Pattberg, P. 2005. What role for private rule-making in global environmental governance? Analysing the Forest Stewardship Council. International Environmental Agreements: Politics, Law and Economics 5(2): 175-189. http://dx.doi.org/10.1007/ $\underline{\text { s10784-005-0951-y }}$

Payne, R. A. 2001. Persuasion, frames and norm construction. European Journal of International Relations 7(1):37-61. http://dx. doi.org/10.1177/1354066101007001002

Raustiala, K., and D. G. Victor. 2004. The regime complex for plant genetic resources. International Organization 58(2):277-309. http://dx.doi.org/10.1017/S0020818304582036

Raymond, C. M, B. A. Bryan, D. H. MacDonald, A. Cast, S. Strathearn, A. Grandgirard, and T. Kalivas. 2009. Mapping community values for natural capital and ecosystem services. Ecological Economics 68(5):1301-1315. http://dx.doi.org/10.1016/ j.ecolecon.2008.12.006

Reinecke, S., T. Pistorius, and M. Pregernig. 2014. UNFCCC and the REDD+ partnership from a networked governance perspective. Environmental Science \& Policy 35:30-39. http://dx. doi.org/10.1016/j.envsci.2012.09.015

Risse, T., S. Ropp, and K. Sikkink, editors. 1999. The power of human rights. International norms and domestic change. Cambridge University Press, Cambridge, UK. http://dx.doi. org/10.1017/CBO9780511598777

Sanz, M. J. 2007. Reducing emissions from deforestation in developing countries (REDD). Presented at COM+ Media Training, Vienna, 29 August. United Nations Framework Convention on Climate Change, Bonn, Germany. [online] URL: http://unfccc.int/files/meetings/intersessional/awg_4_and_dialogue_4/ press/application/pdf/awg4 com plus red.pdf

Schroeder, H. 2008. Analysing biosafety and trade through the lens of institutional interplay. Pages 49-70 in O. R. Young, W. B. Chambers, J. A. Kim, and C. ten Have, editors. Institutional interplay. Biosafety and trade. United Nations University Press, New York, New York, USA.
Schroeder, H. 2010. Agency in international climate negotiations: the case of indigenous peoples and avoided deforestation. International Environmental Agreements. Politics, Law and Economics 10(4):317-332. http://dx.doi.org/10.1007/s10784-010-9138-2

Selin, H., and S. D. VanDeveer. 2003. Mapping institutional linkages in European air pollution politics. Global Environmental Governance 3(3):14-46. http://dx.doi.org/10.1162/152638003322469268

Stokke, O. S., and S. Oberthür. 2011. Introduction: institutional interaction in global environmental change. Pages 1-23 in S. Oberthür, and O. S. Stokke, editors. Managing institutional complexity. Regime interplay and global environmental change. MIT Press, Cambridge, Massachusetts, USA. http://dx.doi. org/10.7551/mitpress/9780262015912.003.0001

Tauli-Corpuz, V., and A. Lynge. 2008. Impact of climate change mitigation measures on indigenous peoples and on their territories and lands. Permanent Forum on Indigenous Issues, New York, New York, USA. [online] URL: http://www.un.org/esa/socdev/ unpfii/documents/E C19 2008 10.pdf

Tebtebba. 2008-2009. Summary report of the South East Asia Indigenous Peoples Regional Consultation on Reducing Emissions from Deforestation and Forest Degradation (REDD). United Nations Framework Convention on Climate Change, Bonn, Germany. [online] URL: https://unfccc.int/files/methods/redd/ submissions/application/pdf/redd_20090217_tebtebba_southeast. pdf

Tebtebba. 2010. Mandaluyong Declaration of the Global Conference on Indigenous Women, Climate Change and REDD Plus. [online] URL: http://www.tebtebba.org/index.php/content/164indigenous-womens-declaration-on-cc-and-redd

Terborgh, J. 2000. The fate of tropical forests: a matter of stewardship. Conservation Biology 14(5):1358-1361. http://dx.doi. org/10.1046/j.1523-1739.2000.00136.x

Toledo, V. M., B. Ortiz-Espejel, L. Cortés, P. Moguel, and M. D. J. Ordoñez. 2003. The multiple use of tropical forests by indigenous peoples in Mexico: a case of adaptive management. Conservation Ecology 7(3): 9. [online] URL: http://www.consecol. org/vol7/iss $3 /$ art9

Underdal, A. 1994. Leadership theory. Rediscovering the arts of management. Pages 178-197 in W. Zartman, editor. International multilateral negotiation. Jossey-Bass, San Francisco, California, USA.

United Nations Framework Convention on Climate Change (UNFCCC). 2006a. Background paper for the workshop on reducing emissions from deforestation in developing countries. UNFCCC, Rome, Italy. [online] URL: http://unfccc.int/ methods and science/lulucf/items/3757.php

United Nations Framework Convention on Climate Change (UNFCCC). 2006b. Issues relating to reducing emissions from deforestation in developing countries and recommendations on any further process. Submissions from Parties. FCCC/SBSTA/2006/ MISC.5. UNFCCC, Bonn, Germany. [online] URL: http:// unfccc.int/resource/docs/2006/sbsta/eng/misc05.pdf

United Nations Framework Convention on Climate Change (UNFCCC). 2006c. Issues relating to reducing emissions from deforestation in developing countries and recommendations on any 
further process. Submissions from Parties. FCCC/SBSTA/2006/ MISC.5, Addendum. UNFCCC, Bonn, Germany. [online] URL: http://unfccc.int/resource/docs/2006/sbsta/eng/misc05a01.pdf

United Nations Framework Convention on Climate Change (UNFCCC). 2007a. Report of the Conference of the Parties on its thirteenth session. Decisions adopted by the Conference of the Parties. FCCC/CP/2007/6/Add.1. UNFCCC, Bonn, Germany. [online] URL: http://unfccc.int/resource/docs/2007/cop13/eng/06a01. pdf

United Nations Framework Convention on Climate Change (UNFCCC). 2007c. Views on issues related to further steps under the Convention related to reducing emissions from deforestation in developing countries: approaches to stimulate action. Submissions from Parties, Addendum. UNFCCC, Bali, Indonesia. [online] URL: http://unfccc.int/resource/docs/2007/sbsta/eng/misc14a03. pdf

United Nations Framework Convention on Climate Change (UNFCCC). 2007b. Views on the range of topics and other relevant information relating to reducing emissions from deforestation in developing countries. FCCC/SBSTA/2007/MISC.2, Addendum. UNFCCC, Bonn, Germany. [online] URL: http://unfccc.int/ resource/docs/2007/sbsta/eng/misc02a01.pdf

United Nations Framework Convention on Climate Change (UNFCCC). 2008. Reducing emissions from deforestation in developing countries: approaches to stimulate action. Conclusions. FCCC/SBSTA/2008/L.23. UNFCCC, Poznan, Poland. [online] URL: http://unfccc.int/resource/docs/2008/sbsta/eng/123.pdf

United Nations Framework Convention on Climate Change (UNFCCC). 2009a. Ad hoc working group on long-term cooperative action under the Convention, sixth session. FCCC/ AWGLCA/2009/INF.1. UNFCCC, Bonn, Germany. [online] URL: http://unfccc.int/resource/docs/2009/awglca6/eng/inf01. pdf

United Nations Framework Convention on Climate Change (UNFCCC). 2009b. Methodological guidance for activities relating to reducing emissions from deforestation and forest degradation and the role of conservation, sustainable management of forests and enhancement of forest carbon stocks in developing countries. Draft decision -/CP.15, Copenhagen, Denmark. [online] URL: http://unfccc.int/files/na/application/pdf/cop15 ddc auv. pdf

United Nations Framework Convention on Climate Change (UNFCCC). 2010a. Report of the Conference of the Parties on its fifteenth session. UNFCCC, Copenhagen, Denmark. [online] URL: http://unfccc.int/resource/docs/2009/cop15/eng/11a01.pdf

United Nations Framework Convention on Climate Change (UNFCCC). 2010b. The Cancun Agreements. Outcome of the work of the Ad Hoc Working Group on Long-term Cooperative Action under the Convention. UNFCCC, Cancun, Mexico. [online] URL: http://unfccc.int/resource/docs/2010/cop16/eng/07a01. pdf\#page $=2$

United Nations General Assembly (UNGA). 2007. United Nations Declaration on the Rights of Indigenous Peoples. Resolution A/RES/61/295. UNGA, New York, New York, USA. [online] URL: http://www.un.org/ga/search/view doc.asp?symbol= A/RES/61/295

United Nations Permanent Forum on Indigenous Issues (UNPFII). 2006. Fact sheet 1: indigenous peoples and identity. UNPFII, United Nations Department of Economic and Social Affairs, New York, New York, USA. [online] URL: http://social. un.org/index/IndigenousPeoples/UNPFIISessions/PreviousSessions/ Fifth.aspx

Visseren-Hamakers, I. J., C. McDermott, M. J. Vijge, and B. Cashore. 2012. Trade-offs, co-benefits and safeguards: current debates on the breadth of REDD+. Current Opinion in Environmental Sustainability 4(6):646-653. http://dx.doi.org/10.1016/ j.cosust.2012.10.005

Werksman, J. 2010. The legal character and legitimacy of the Cancun Agreements. World Resources Institute, Washington, D. C., USA. [online] URL: http://www.wri.org/stories/2010/12/qalegal-character-and-legitimacy-cancun-agreements

Wiener, A. 2007. The dual quality of norms and governance beyond the state: sociological and normative approaches to 'interaction'. Critical Review of International Social and Political Philosophy 10(1):47-69. http://dx.doi.org/10.1080/13698230601122412

Young, O. R. 1991. Political leadership and regime formation: on the development of institutions in international society. International Organization 45(3):281-308. http://dx.doi.org/10.1017/ $\underline{\mathrm{S} 0020818300033117}$

Zelli, F., A. Gupta, and H. van Asselt. 2012. Horizontal institutional interlinkages. Pages 175-198 in F. Biermann and P. Pattberg, editors. Global environmental governance reconsidered: new actors, mechanisms and interlinkages. MIT Press, Cambridge, Massachusetts, USA. 